\title{
QUALITY OF TOMATOES GROWN UNDER A PROTECTED ENVIRONMENT AND FIELD CONDITIONS
}

\author{
CALIDAD DE LOS TOMATES PRODUCIDOS EN CONDICIONES \\ DE AMBIENTE PROTEGIDO Y ABIERTAS
}

\author{
Fabiano Ricardo Brunele Caliman ${ }^{1}$; Derly José Henriques da Silva ${ }^{2 *}$; Paulo César Stringheta ${ }^{3}$; \\ Paulo Cezar Rezende Fontes ${ }^{4}$; Gisele Rodrigues Moreira ${ }^{5}$; Everardo Chartuni Mantovani ${ }^{6}$
}

\begin{abstract}
The growth environment of a tomato affect its composition. To quantify such effects, two experiments were carried out, one in a protected environment (greenhouse covered with a plastic film) and the other (unprotected natural) under field conditions, using the tomato cultivar 'Santa Clara', the hybrid 'Carmem' and the accession 'BGH-320'. Fruits produced in the field had higher TSS/TA ratio, acidity and had more reducing sugar, ascorbic acid, and TSS than those produced in protected conditions. Among the tomato genotypes evaluated, 'Carmem' and 'Santa Clara' fruits had higher TSS/TA ratio than accession 'BGH-320' fruit, contained a higher content of reducing sugars and had a higher $\mathrm{pH}$. Fruits of accession 'BGH-320' were more acidic and had a higher lycopene content than those of the 'Carmem' and 'Santa Clara'. The ascorbic acid content of 'Santa Clara' fruit was higher than that of the other genotypes. No difference was found in the potassium contents of fruits among the genotypes grown in the same environment. However, when comparing environments, 'Santa Clara' tomato fruit had a higher potassium level when grown under field conditions.
\end{abstract}

Key words: Ascorbic acid, lycopene, Lycopersicon esculentum, reducing sugar.

\section{RESUMEN}

El ambiente de cultivo puede afectar la composición del tomate. Para cuantificar estos efectos se realizaron dos experimentos, uno en condiciones de cultivo protegido (cubierto con una película de plástico de $150 \mathrm{m \mu}$ ) y el otro sin protección, en condiciones abiertas, utilizando el cultivar de tomate 'Santa Clara', el híbrido 'Carmen'y el acesso 'BGH-320'. Los frutos producidos en el campo tenían mayor acidez, mayor contenido de sólidos solubles totales, mayor relación TSS/TA, más contenido de azúcar y ácido ascórbico que los producidos en condiciones protegidas. Entre los genotipos de tomate evaluados, los frutos del 'BGH-320'fueron más ácidos y con mayor contenido de licopeno que los frutos del cultivar 'Carmen' y el híbrido 'Santa Clara'. Por otro lado, los frutos de 'Carmen' y 'Santa Clara' tuvieron mayor pH, mayor relación TSS/TA y mayor contenido de azúcares reductores que los frutos del 'BGH-320'. El contenido de ácido ascórbico de los frutos del 'Santa Clara' fue superior al de los otros genotipos. No se encontraron diferencias en el contenido de potasio de los frutos entre los genotipos cultivados en el mismo ambiente. Sin embargo, cuando se comparan los ambientes de cultivo, en los frutos de tomate 'Santa Clara' producidos en campo había un mayor nivel de potasio.

Palabras clave: Ácido ascórbico, licopeno, Lycopersicon esculentum, azúcares reductores.

1 Department of Plant Science, Federal University of Viçosa, Viçosa, MG, Brazil.

Cep 36570-000. Phone: 55 + 313899 1166. Fax number: 55 + 313899 2614. E-mail: frcaliman@ yahoo.com.br

2 Department of Plant Science, Federal University of Viçosa, Viçosa, MG, Brazil.

Cep 36570-000. Phone: 55 + 313899 1166. Fax number: 55 + 313899 2614. E-mail: derly@ufv.br

3 Department of Food Technology, Federal University of Viçosa, Viçosa, MG, Brazil. Cep 36570-000.

4 Department of Plant Science, Federal University of Viçosa, Viçosa, MG, Brazil.

Cep 36570-000. Phone: 55 + 313899 1166. Fax number: 55 + 313899 2614. E-mail: pacerefo@ufv.br

5 Federal University of Piauí, Campus Cenobelina Elvas, Rodovia BR 135, Km 03, Vila Estela, Bom Jesus, Piauí, Brazil. Cep 64900-000.

6 Department of Agricultural Engineering, Federal University of Viçosa, Viçosa, MG, Brazil. Cep 36570-000.

* Autor for correspondence: Derly José Henriques da Silva. Departamento de Fitotecnia, Universidade Federal de Viçosa, Viçosa, Minas Gerais, Brazil. Cep 36570-000. Phone 55 + 313899 1166. Fax number: 55 + 313899 2614. E-mail: derly@ ufv.br 


\section{INTRODUCTION}

Tomato fruit contains 92.5 - 95\% water and $5-7.5 \%$ dry matter (DM) (Davies and Hobson, 1981). The DM consists of sugars, mainly glucose and fructose, which account for approximately $48 \%$ of the sugars; organic acids, $13 \%$ citric and malic acid; minerals, mainly $\mathrm{N}, \mathrm{P}$ and $\mathrm{K}(8 \%)$, and a small, though nutritionally important, fraction composed of vitamins and anti-oxidant pigments such as lycopene.

Besides its importance for consumption, fruit acidity affects the industrialisation processes by reducing of $\mathrm{pH}$ of the pulp and preventing the growth of microorganisms that are harmful to the conservation of the product (Carvalho, 1980). Moreover, low pH decreases the period of heating needed for sterilisation during processing (Stevens, 1972).

Total soluble solids contents (TSS) are important for the industrialisation process as product yield is directly related to ${ }^{\circ} \mathrm{Brix}$, especially when the objective is dehydration, concentration of the pulp, or both (Stevens, 1972).

Lycopene, ascorbic acid (vitamin C), and potassium contents are important for the nutritional value of tomato; they have beneficial effects on human health. Franceschi et al. (1994) and Frusciante et al. (2000) reported that the consumption of the tomato and its subproducts (i.e., ketchup, paste) is negatively correlated with the development of tumours in the digestive tract and prostate cancer.

Vitamin $\mathrm{C}$ plays an important role in human health and it is found in fruits and vegetables in the form of ascorbic acid. Its main functions are in the prevention of scurvy and maintenance of skin and blood vessels (Lee and Kader, 2000).

Several factors, such as genotype, may affect the DM composition of a tomato, including vitamin C, lycopene and potassium contents. Orange-colored tomato cultivars have high contents of carotenoids and volatile compounds, while yellow fruit cultivars have a lycopene content 10-fold lower than red coloured fruit cultivars (Hart and Scott, 1995). Wild species may have twice as much lycopene and vitamin C as commercial cultivars (Dorais et al., 2001). Besides being influenced by genotype, some fruit constituents are also influenced by environmental conditions. For example, vitamin $\mathrm{C}$ and lycopene contents are strongly affected by light intensity and temperature (Venter, 1977; Chang et al., 1977; Davies and Hobson, 1981).
In traditional vegetable-producing regions, tomato cultivation in a protected environment has expanded to prevent seasonality in the availability of fruit (Andriolo, 2000). Alterations in light intensity, temperature and relative humidity occur in protected environments and can affect production and the partitioning of photo-assimilates in the plant and, consequently, the composition of the produced fruit (Martinez, 1994; Bakker, 1995).

This work aimed to evaluate the effect of different cultivation environments in three tomato genotypes on flavour traits, titratable acidity (TA), $\mathrm{pH}$, reducing sugar, total soluble solids (TSS), TSS/ TA ratio, lycopene, ascorbic acid, and potassium contents in tomato.

\section{MATERIALS AND METHODS}

Two experiments were carried out, one in a protected environment (non-heated greenhouse) and the other in a field at the Olericulture Sector, Department of Plant Sciences, Federal University of Viçosa, Viçosa, Minas Gerais, Brazil. The experiments were arranged in a randomised complete block design, with six repetitions of three genotypes: 'Santa Clara', the hybrid 'Carmem' and an accession from the Vegetable Germplasm Bank of the UFV, 'BGH-320', which was selected as it displayed good fruit quality relative to 34 accessions in the germplasm bank (Caliman et al., 2002).

The protected environment experiment was conducted in a non-heated greenhouse (10 $\mathrm{m}$ wide, $40 \mathrm{~m}$ long and $5 \mathrm{~m}$ high) with retractable lateral shades and a plastic film cover $(150 \mu \mathrm{m})$. The field experiment was conducted under natural conditions, without protection.

The seedlings were produced in styrofoam trays (128 cells) where they were kept for 20 days after sowing and were later simultaneously transferred into the soil of both environments.

Drip irrigation and weekly fertigations were applied in both experiments, with $304 \mathrm{~kg} \mathrm{~N} \mathrm{ha}^{-1}$ and $180 \mathrm{~kg} \mathrm{~K} \mathrm{ha}^{-1}$ being supplied throughout the growing cycle.

Cultivation was conducted under conventional systems and harvests were performed when fruits reached the completely ripe stage, with $100 \%$ of their surface presenting red colouration. Eight fruits per repetition were harvested and hygienized forming one composed sample that was submitted for analytical 
processing. The following traits were analysed in the fruits: a) titratable acidity (TA), determined by titration of the compost homogenized powder sample with $0.01 \mathrm{~N} \mathrm{NaOH}$ using fenolftaleine-indicator (expressed as\% citric acid); b) $\mathrm{pH}$, determined in $50 \mathrm{~g}$ samples of pulp with a digital $\mathrm{pH}$-meter; c) total soluble solids (TSS), determined with a digital refractometer; d) TSS/TA ratio, a flavour indicator as described by Kader et al. (1978); e) reducing sugar content, by applying the method of Dubois et al. (1956) as modified by Johnson et al. (1966); f) total carotenoids, expressed as "lycopene", using spectrophotometry, with a T max of $472 \mathrm{~nm}$ and a molar extinction coefficient of $E_{1 \mathrm{~cm}}{ }^{1 \%}=3450$ (Tan, 1988; Hart and Scott, 1995); g) ascorbic acid content, determined by titration with 2,6-dichlorophenolindophenol, according to the AOAC (1975); and h) potassium content, as extracted from fruit using nitric-perchloric digestion and determined by flame photometry. Fruit carotenoids were not separated in this work. Lycopene was used as an indicator of the contribution of all of the other pigments, as the red colour is attributed to this carotenoid, and since it constitutes approximately $80 \%$ and can reach $\geq 90 \%$ of total carotenoids (Dorais et al., 2001).

The results were submitted to joint analysis for both environments (Steel et al., 1997). Mean values were compared by Tukey's test $(P<0.05)$, using the Statistical and Genetic Analysis System (SAEG).

\section{RESULTS AND DISCUSSION}

A significant effect of crop environments was verified by the traits TA, TSS, SST/AT ratio, reducing sugar content, and ascorbic acid, while $\mathrm{pH}$ and "lycopene" content were not influenced by crop environment. Differences were found between genotypes for quality traits analysed, except $\mathrm{K}^{+}$ content, which varied significantly between genotypes and cropping environment, and TSS.

Field-produced fruits were more acidic (greater AT) than fruits produced in a protected environment (Table I). The environmental effect on fruit acidity is complex and some studies favor the hypothesis that organic acids are produced in the fruit itself from stored carbohydrates (Sakiyama and Stevens, 1976), although some of these acids may be translocated from the leaves and roots to the fruits (Bertin et al., 2000). Thus, the lower acidity of the fruits grown in the protected environment may be a result of the lower photosynthetic activity of the plant (shading in protected environment) in this environment and lower carbohydrate accumulation in the fruits. Among the genotypes, access ' $\mathrm{BGH}$ 320 ' fruits were more acidic than 'Carmem' and 'Santa Clara' fruits (Table I). According to Mahakun et al. (1979), the genetic factor is the major acid content determinant in tomato plant fruits, with great variation occurring between genotypes (Stevens and Rick, 1986). These authors reported variation in fruit acidity (\% citric acid) for different accessions of Lycopersicon esculentum, from $0.40 \%$ to $0.91 \%$; Stevens et al. (1979) and Mitchell et al. (1991) found lower citric acid percentage values, down to $0.25 \%$. Loures (2001), evaluating the hybrid 'Carmem', found fruit titratable acidity (\% citric acid) of $0.46 \%$ and $0.49 \%$ under greenhouse and field conditions, respectively. During fruit development, acidity increases, reaching a maximum value at the first signs of yellow coloration (breaker stadium) and progressively decreasing with the appearance of the red color (Davies and Hobson, 1981) as the fruit reaches complete maturity (Hobson, 1987). The acidity values of the fruits analyzed in this work were relatively low, mainly for 'Santa Clara' cultivar fruits. The determination of fruit acidity at complete maturation, when acidity declines, is likely the reason for the low values.

'Carmem' and 'Santa Clara' fruits showed a higher $\mathrm{pH}$ than 'BGH-320' fruits (Table I). These values agree with those of Stevens and Rick (1986), who reported a tomato fruit $\mathrm{pH}$ between $4.26-4.82$ for different Lycopersicon esculentum accessions.

The TSS content observed in fruits analysed in this work varied between $3,60^{\circ} \mathrm{Brix}-5,93^{\circ} \mathrm{Brix}$ and were higher than the $3.57-3.75$ variation observed by Ferreira (2001) when evaluating 'Santa Clara' cultivar fruits produced in the field. Loures (2001) found a TSS content of 4.77 and 4.95 for 'Carmem', grown in the field and in a protected environment, respectively. Tomato SST is mostly composed of reducing sugar (Ho and Hewitt, 1986). Thus, any factor that alters sucrose synthesis (photosynthetic activity) will affect glucose and fructose accumulation in the fruits, thus altering TSS.

Fruits produced in the field had greater SST/AT ratios than those produced in a protected environment (Table I). Among the genotypes, 'Carmem' and 'Santa Clara' fruit presented greater SST/AT ratios than the 'BGH-320' fruits. Tomato had a good flavour when 
Table I

Fruit quality characteristics of the different genotypes grown in different environments

\begin{tabular}{|c|c|c|c|c|}
\hline \multirow{2}{*}{ Environment } & \multicolumn{4}{|c|}{ Tomato plant genotype } \\
\hline & BGH-320 & Carmem & Santa Clara & Total average \\
\hline \multicolumn{5}{|c|}{ Titratable acidity (\% citric acid) } \\
\hline Protected & 0.37 & 0.30 & 0.26 & $0.31 \mathrm{~b}$ \\
\hline Field & 0.44 & 0.31 & 0.30 & $0.35 \mathrm{a}$ \\
\hline Total average & $0.40 \mathrm{~A}$ & $0.30 \mathrm{~B}$ & $0.28 \mathrm{~B}$ & \\
\hline \multicolumn{5}{|c|}{$\mathrm{pH}$} \\
\hline Protected & 4.34 & 4.54 & 4.56 & 4.48 \\
\hline Field & 4.37 & 4.59 & 4.51 & 4.49 \\
\hline Total average & $4.35 \mathrm{~B}$ & $4.56 \mathrm{~A}$ & $4.53 \mathrm{~A}$ & \\
\hline \multicolumn{5}{|c|}{ SST $\left({ }^{\circ}\right.$ Brix $)$} \\
\hline Protected & 3.83 & 3.62 & 3.60 & $3.68 \mathrm{~b}$ \\
\hline Field & 5.82 & 5.20 & 5.93 & $5.65 \mathrm{a}$ \\
\hline Total average & $4.82 \mathrm{~A}$ & $4.41 \mathrm{~A}$ & $4.76 \mathrm{~A}$ & \\
\hline \multicolumn{5}{|c|}{ SST/AT } \\
\hline Protected & 10.33 & 12.17 & 13.72 & $12.07 \mathrm{~b}$ \\
\hline Field & 13.59 & 17.07 & 19.81 & $16.82 \mathrm{a}$ \\
\hline Total average & $11.96 \mathrm{~B}$ & $14.62 \mathrm{~A}$ & $16.76 \mathrm{~A}$ & \\
\hline \multicolumn{5}{|c|}{ Reducing Sugars (g $100 \mathrm{~g}^{-1}$ fresh fruit) } \\
\hline Protected & 1.80 & 2.35 & 2.05 & $2.06 \mathrm{~b}$ \\
\hline Field & 2.31 & 2.86 & 2.98 & $2.71 \mathrm{a}$ \\
\hline Total average & $2.05 \mathrm{~B}$ & $2.60 \mathrm{~A}$ & $2.51 \mathrm{~A}$ & \\
\hline \multicolumn{5}{|c|}{ Lycopene (mg $100 \mathrm{~g}^{-1}$ fresh fruit) } \\
\hline Protected & 8.88 & 6.95 & 7.62 & 7.81 \\
\hline Field & 8.82 & 6.75 & 6.86 & 7.47 \\
\hline Total average & $8.85 \mathrm{~A}$ & $6.85 \mathrm{~B}$ & $7.24 \mathrm{~B}$ & \\
\hline \multicolumn{5}{|c|}{ Ascorbic acid (mg $100 \mathrm{~g}^{-1}$ fresh fruit) } \\
\hline Protected & 12.70 & 12.03 & 13.76 & $12.83 \mathrm{~b}$ \\
\hline Field & 15.23 & 14.17 & 21.66 & $17.02 \mathrm{a}$ \\
\hline Total average & $13.96 \mathrm{~B}$ & 13.10B & $17.71 \mathrm{~A}$ & \\
\hline
\end{tabular}

Averages followed by same capital letter in the line do not differ by Tukey's test $(P<0.05)$;

Averages followed by same lower-case letter in the columns do not differ by the F-test $(P<0.05)$. 
presenting a TSS/TA ratio $\geq 10$ (Kader et al.,1978; Mencarelli and Saltveit, 1988). The three genotypes evaluated here had TSS:TA ratios $\geq$ to 10 , thus being adequate for fresh consumption. Kader et al. (1978) suggest that high quality fruits should have values TA $>0.32 \%$ and TSS values $>3 \%$. 'Santa Clara' and the hybrid 'Carmem' did not reach these minimum acidity values.

Regarding reducing sugar contents, fruits produced in the field had higher contents than fruits produced in the protected environment. Among the genotypes, 'Carmem' and 'Santa Clara' presented higher reducing sugar contents than 'BGH-320' fruit (Table I).

The lower reducing sugar content of fruits produced in the protected environment may be related to lower light intensity, approximately $25 \%$ lower than in the field, accord to Martins et al. (1999) and Beckmann et al. (2006). Provided it is within the limits that are not harmful to the photosynthetic system, higher luminosity enhances the photosynthetic activity of the plants. Thus, the greater sugar content in the fruits produced in the field may be due, in part, to the greater light intensity in this crop environment and greater photosynthetic plant activity.

The content of reducing sugar in the appraised fruits is in agreement with those reported in the literature. Davies and Hobson (1981) reported

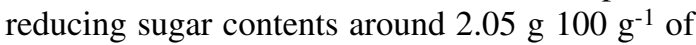
fresh fruit for the protected environment and 2,93 $\mathrm{g}$ $100 \mathrm{~g}^{-1}$ of fresh fruit for field cultivation. According to these authors, there may be a great variation in the content of reducing sugars $\left(1,66 \mathrm{~g}-3,99{\left.\mathrm{~g} 100 \mathrm{~g}^{-1}\right)}^{-1}\right.$ among genotypes, even when they are cultivated in the same environment.

Genotype influenced the "lycopene" content of fruit, while the environment did not influence this characteristic (Table I). The "lycopene" contents in the fruits of the evaluated genotypes are in agreement with the values presented by Frusciante et al. (2000), ranging from $5.5 \mathrm{mg}-7.5 \mathrm{mg} 100 \mathrm{~g}^{-1}$ of fresh fruit and from $2.5 \mathrm{mg}-14.8 \mathrm{mg} 100 \mathrm{~g}^{-1}$ of fresh fruits of cultivars and hybrids, respectively and by Camargos (1998), who evaluated the hybrid Carmem cultivated in a greenhouse with values ranging from $6.25 \mathrm{mg}-8.72 \mathrm{mg} 100 \mathrm{~g}^{-1}$ of fresh fruit. Values ranging from $4.36 \mathrm{mg}-18.1 \mathrm{mg} 100 \mathrm{~g}^{-1}$ of fresh fruit are found in the literature (Meredith and Purcell, 1966; Davies and Hobson, 1981; Hart and Scott, 1995), with this variation being attributed to crop environments and different genotypes.
Field-produced fruits were expected to show a higher lycopene content than fruits produced in a protected environment since, under favorable temperatures $\left(22^{\circ}-25^{\circ} \mathrm{C}\right)$, lycopene biosynthesis is stimulated by luminosity, which was approximately $25 \%$ more intense in the field. In addition, plants tend to adapt to adverse climate conditions such as greater luminosity, by forming thick waxy layers and greater pigmentation (Pearce et al., 1993).

Field-grown plants were exposed to rainfall and periods of low temperature, which favoured the development of the fungus Phytophthora infestans. This fungus reduced the leaf area of the plant, which exposed the fruits to direct sunlight. According to Grierson and Kader (1986), when tomato fruits are exposed to direct radiation, their temperature may be increased up to $10^{\circ} \mathrm{C}$ above the environmental air temperature. By exposing the fruits to intense luminosity, plant defoliation may have increased fruit temperature to values which are unfavorable for lycopene biosynthesis, thus causing the fruits grown in the field to present lycopene contents similar to those presented by the fruits grown in protected environments.

'Santa Clara' fruits showed a higher content of ascorbic acid (Table I). Ascorbic acid biosynthesis can be strongly influenced by environmental cultivation conditions, with light intensity affecting the content of ascorbic acid in tomato fruits (Venter, 1977). Besides climatic conditions, the genotype has a great effect on ascorbic acid content in tomato. The ascorbic acid contents of the fruits analyzed in this work are in agreement with Davies and Hobson (1981), who reported a variation between 10 and $30 \mathrm{mg}$ of ascorbic acid per $100 \mathrm{~g}$ of fresh fruit in a protected environment and in the field, as well as among different genotypes. Stevens and Rick (1986) reported, however, ascorbic acid content variations for different genotypes from $8 \mathrm{mg}$ - $130 \mathrm{mg} 100 \mathrm{~g}^{-1}$ of fresh fruit. Loures (2001) obtained $4.80 \mathrm{mg}$ and $5.65 \mathrm{mg}$ ascorbic acid $100 \mathrm{~g}^{-1}$ of fresh weight of 'Carmem' fruits produced in a greenhouse and in the field, respectively.

Despite not being essential for ascorbic acid synthesis, luminosity may affect its accumulation during the growth of the plant and fruit. Ascorbic acid is synthesized from photosynthesis-produced sugars (Lee and Kader, 2000). As previously mentioned, sugar production is a function of the plant's photosynthetic rate, which, in turn, is a function of luminosity intensity. Thus, a lower 
ascorbic acid content of the fruits produced in a protected environment is probably caused by the lower luminosity in this environment, which may have reduced the production of sugar, a substrate that is used in the synthesis of ascorbic acid.

There was a significant statistical interaction between genotypes and crop environments for potassium content of the fruit (Table II). 'Santa Clara' cultivar fruits showed a higher potassium content in the field. Considering the crop environments, potassium content of the three genotypes of fruits did not differ. 'BGH-320' and 'Carmem' fruit showed similar contents in both crop environments.

Potassium content in the fruits analyzed in this work ranged from $3.90-4.56 \mathrm{mg} 100 \mathrm{~g}^{-1}$ of DM, slightly over the values from 3 - $4 \mathrm{mg} 100 \mathrm{~g}^{-1}$ cited by Ho and Hewitt (1986). Potassium content in the soil where the protected environment experiment was installed was inferior to that in the field experiment, a difference that may have contributed to the differences in potassium contents in the fruits.

The major source of energy for nonphotosynthesing cells and tissues is respiration. The carbohydrates produced during photosynthesis are the main substrates for this process, as cited by Marschner (1995). This author reports a positive correlation between carbohydrate content and ion accumulation (such as potassium) in roots, fruits, and other non-synthesizing organs, under conditions of poor carbohydrate supply in the source tissues (leaves). Therefore, any factor that may affect the availability of carbohydrate for respiration may also affect ion accumulation. In other words, lower luminosity in the protected environment may have contributed to photosynthesis reduction and carbohydrate availability in the respiratory process, leading to a lower potassium content in the fruits.

Besides the difference in light intensity, another altered climatic factor in the protected environment was relative humidity. Relative humidity values in the protected environment were around 10\% higher than those in the field (data not show). High relative air humidity can reduce plant transpiration and promote xylematic flux of water, which is favorable to the fruits, since the fruits act as drains for high concentrations of organic molecules and, consequently, low water potential (Bertin et al. 2000). Thus, absorption of water by the fruits may have been favored in the protected environment and, consequently, may have led to a "dilution effect", causing the fruits grown in the protected environment to be less flavorful and have lower contents of soluble solids, reducing sugar and ascorbic acid contents than the fruits grown in the field.

\section{CONCLUSION}

In a general way, fruits produced in the field presented better quality that fruits produced in protected environment. Field-grown fruits were more tasteful and acid and its sugar reducing, SST and ascorbic acid contents were higher than those of the fruits grown in a protected environment. Among the genotypes, accession BGH-320 fruits were more acid and with higher $\mathrm{pH}$ and "lycopene" content than the fruits of the other genotypes. 'Carmem' and 'Santa Clara' fruits were more tasteful and had a higher content of reducing sugars than the other genotypes. 'Santa Clara' fruits showed

Table II

Potassium contents (mg $100 \mathrm{~g}-1 \mathrm{DM}$ ) in accession 'BGH-320', hybrid 'Carmem' and cultivar 'Santa Clara' fruits, grown under protected and field environments

\begin{tabular}{|l|l|l|l|c|}
\hline \multirow{2}{*}{ Environment } & \multicolumn{3}{|c|}{ Genotype } & \multirow{2}{*}{ Environment average } \\
\cline { 2 - 5 } & 'BGH-320' & 'Carmem' & 'Santa Clara' & 4.08 \\
\hline Protected & $4.26 \mathrm{Aa}$ & $4.08 \mathrm{Aa}$ & $3.90 \mathrm{Ab}$ & 4.33 \\
\hline Field & $4.16 \mathrm{Aa}$ & $4.31 \mathrm{Aa}$ & $4.53 \mathrm{Aa}$ & \\
\hline Genotype average & 4.21 & 4.19 & 4.21 & \\
\hline
\end{tabular}

Averages followed by the same capital letter in the line do not differ by the Tukey's test $(P<0.05)$.

Averages followed by same lower-case letter in a column do not differ by the F-test $(P<0.05)$. 
higher ascorbic acid and potassium contents when grown in the field. Considering the environments individually, potassium content of the fruits of the three genotypes did not differ.

\section{LITERATURE CITED}

ANDRIOLO, J.L. 2000. Fisiologia da produção de hortaliças em ambiente protegido. Horticultura Brasileira 18, 26-33.

ASSOCIATION OF ANALYTICAL CHEMISTS, 1975. Official Methods of Analysis. 12th Edition. Washington DC USA, $1094 \mathrm{pp.}$

BECKMANN, M.Z.; DUARTE, G.R.B.; DE PAULA, V.A.; GONZÁLES-MENDES, M.A.; PIEL, R.M.N. 2006. Radiação solar em ambiente protegido cultivado com tomateiro nas estações verão-outono do Rio Grande do Sul. Ciência Rural, Santa Maria, v. 36, n. 1, p. 86-92.

BAKKER, J.C. 1995. Greenhouse climate control: constraints and limitations. Acta Horticulturae 399, 25-35.

BERTIN, N.; GHICHARD，N.; LEONARDI，C.; LONGUENESSE, J.J.; LANGLOIS, D.; NAVES, B. 2000. Seasonal evolution the quality of fresh glasshouse tomato under Mediterranean conditions, as affected by vapour pressure deficit and plant fruit load. Annals of Botany 85, 741-750.

CALIMAN, F.R.B.; MARIN, B.G.; STRINGHETA, P.C.; SILVA, D.J.H.; MOREIRA, G.R.; ABREU, F.B. 2002. Caracterização da qualidade de frutos de 32 acessos de tomateiro do Banco de Germoplasma de Hortaliças da UFV. Horticultura Brasileira, suplemento 22, p. 388

CAMARGOS, M.I. 1998. Produção e Qualidade de Tomate Longa Vida em Estufa, em Função do Espaçamento e do Número de Cachos por Planta. M.Sc. Thesis, Universidade Federal de Viçosa, Viçosa, Brazil, 67 pp.

CHANG, Y.; RAYMUNDO, L.C.; GLASS, R.W.; SIMPSON, K.L. 1977. Effect of high temperature on CPTA-induced carotenoid biosynthesis in ripening tomato fruits. Journal of Agricultural and Food Chemistry 25, 1249-1261.

CARVALHO, V.D. 1980. Características químicas e industriais do tomate. Informe Agropecuário 6, 63-68.

DAVIES, J.N.; HOBSON, G.E. 1981. The constituents of tomato fruit - the influence of environment, nutrition, and genotype. Critical Reviews in Food Science and Nutrition $15,205-280$.

DORAIS, M.; GOSSELIN, A.; PAPADOPOULOS, A.P. 2001. Greenhouse tomato fruit quality. Horticultural Reviews 26, 239-306

DUBOIS, M.; GILES, K.A.; HAMILTON, J.K.; REBERS P.A.; SMITH, F. 1956. Colorimetric method for determination of sugar and related substances. Analytical Chemistry 28, 350-356.

FERREIRA, M.M.M. 2001. Índice de Nitrogênio para o Diagnóstico do Estado Nutricional do Tomateiro em Presença e Ausência de Adubação Orgânica. Ph.D. Thesis, Universidade Federal de Viçosa, Viçosa, Brazil. 154 pp.

FRANCESCHI, S.; BIDOLI, E.; LA VECCHIA, C. TALAMINI, R.; D'AVANZO, B.; NEGRI, E. 1994. Tomatoes and risk of digestive-tract cancers. International Journal of Cancer 59, 181-184.

\section{ACKNOWLEDGEMENTS}

We thank CNPq for granting financial resources.

FRUSCIANTE, L.; BARONE, B.; CARPUTO, D.; ERCOLANO, M.R.; DELLA ROCA, F.; ESPOSITO, S. 2000. Evaluation and use of plant biodiversity for food and pharmaceuticals. Fitoterapia 71, 66-72.

GRIERSON, D.; KADER,A.A. 1986. Fruit ripening and quality. In: The Tomato Crop. A Scientific Basis for Improvement. (Atherton, J.G., Rudich, J., Eds.). Chapman \& Hall, New York, USA. 241-281.

HART, D.J.; SCOTT, K.J. 1995. Development and evaluation of an HPLC method for the analysis of carotenoids in foods, and the measurement of the carotenoid content of vegetables and fruits commonly consumed in the UK. Food Chemistry 54, 101-111.

HO, L.C.; HEWITT, J.D. 1986. Fruit development. In: The Tomato Crop. A Scientific Basis for Improvement. (Atherton, J.G., Rudich, J., Eds.). Chapman \& Hall, New York, USA. 201-239.

HOBSON, G.E. 1987. Low-temperature injury and the storage of ripening tomatoes. Journal of Horticultural Science, 62, 55-62.

JOHNSON, R.R.; BALWANI, T.L.; JOHNSON, L.J.; MCCLURE, K.E.; DEHORITY, B.A. 1966. Corn plant maturity. II. Effect on in vitro cellulose digestibility and soluble carbohydrate content. Journal of Animal Science, 25, 612-623.

KADER,A.A.; MORRIS, L.L.; STEVENS, M.A.; ALBRIGHTHOLTON, M. 1978. Composition and flavor quality of fresh market tomatoes as influenced by some postharvest handling procedures. Journal of the American Society for Horticultural Science 113, 742-745.

LEE, S.K.; KADER, A.A. 2000. Preharvest and postharvest factors influencing vitamin $\mathrm{C}$ content of horticultural crops. Postharvest Biology and Technology, 20, 207-220.

LOURES, J.L. 2001. Estabelecimento e avaliação do sistema de produção denominado Fito, em estufa e campo. Ph.D.Thesis. Universidade Federal de Viçosa, Viçosa, Brazil. 109 pp.

MARTINS, S.R.; FERNANDES, H.S.; DE ASSIS, F.N.; MENDEZ, M.E.G. 1999. Caracterização climática e manejo de ambientes protegidos: a experiência brasileira. Informe Agropecuário, Belo Horizonte, v. 20, n. 200/201, p. $15-23$.

MAHAKUN, N.; LEEPER, P.W.; BURNS, E.E. 1979. Acidic constituents of various tomato fruit types. Journal of Food Science 44, 241-244.

MARSCHNER, H. 1995. Mineral nutrition of higher plants. 2nd Edition. Academic Press, New York, USA. 824 pp.

MARTINEZ, P.F. 1994. The influence of environmental conditions of mild winter climate on the physiological behaviour of protected crops. Acta Horticulturae 357, 29-38.

MENCARELLI, F.; SALTVEIT, M.E. JR. 1988. Ripening of mature-green tomato fruit slices. Journal of the American Society Horticultural Science, 113, 742-745. 
MEREDITH, F.I.; PURCELL, E.A. 1966. Changes in the concentration of carotenes of ripening homestead tomatoes. Proceedings of the American Society for Horticultural Science 89, 544

MITCHELL, J.P.; SHENNAN, C.; GRATTAN, S.R.; MAY, D.M. 1991. Tomato fruit yields and quality under water deficit and salinity. Journal of American Society for Horticultural Science 116, 215-221.

PEARCE, B.D.; GRANGE, R.I.; HARDWICK, K. 1993. The growth of young tomato fruit. II. Environmental influences on glasshouse crops grown in rockwool or nutrient film. Journal of Horticultural Science 68, 12-13.

SAKIYAMA, R.; STEVENS, M.A. 1976. Organic acid accumulation in attached and detached tomato fruits. Journal of the American Society for Horticultural Science 101, 394-396.

STEEL, R.G.D.; TORRIE, J.H.; DICKEY, D.A. 1997. Principles and Procedures of Statistics: a Biometrical
Approach. 3nd Edition. McGraw-Hill. New York, USA. $666 \mathrm{pp}$.

STEVENS, M.A. 1972. Citrate and malate concentrations in tomato fruits: genetic control and maturational effects. Journal of the American Society for Horticultural Science 97, 655-658.

STEVENS, M.A.; KADER, A.A.; ALBRIGHT, M. 1979. Potential for increasing tomato flavor via increased sugar and acid content. Journal of the American Society for Horticultural Science 104, 40-42.

STEVENS, M.A.; RICK, C.M. 1986. Genetics and breeding In: The Tomato Crop. A Scientific Basis for Improvement (Atherton, J.G., Rudich, J., Eds.). Chapman \& Hall, New York, USA. 34-109 pp.

TAN, B. 1988. Analytical and preparative chromatography of tomato paste carotenoids. Journal of Food Science 53, 954-959.

VENTER, F. 1977. Solar radiation and vitamin C content of tomato fruits. Acta Horticulturae 58, 121-127. 